\title{
Verrucous Carcinoma Arising Secondary to Diabetic Foot Lesions: A Systematic Review of the Literature
}

\author{
Kayla Neville, MS ${ }^{1}$, Aleksandar Obradovic, MPhil2,3 \\ ${ }^{1}$ New York College of Podiatric Medicine, New York, NY \\ ${ }^{2}$ Department of Systems Biology, Columbia University Irving Medical Center, New York, NY \\ ${ }^{3}$ Columbia University Center for Translational Immunology, New York, NY
}

\section{ABSTRACT}

Verrucous carcinoma is classically considered a variant of squamous cell carcinoma, most commonly occurring in the oral cavity in association with snuff and chewed tobacco. However, the association between verrucous carcinoma of the foot and diabetes is less well known. This study presents a systematic review of all articles containing the search term "verrucous carcinoma" and "diabetic foot ulcer" in the abstract or title that have been published in PubMed before September 2020. The requirement for inclusion in our report were that the patient data had been documented in a caserelated manner and the patient diagnosed with verrucous carcinoma secondary to diabetic foot lesion. Seven descriptions of verrucous carcinoma presenting in patients with diabetic foot ulcers were presented across six case reports, and clinical case descriptions are collected here along with treatment outcomes, where available, and discussion of common mimics of verrucous carcinoma of the foot. Due to treatability and potential for extensive invasion of local structures requiring resection with wide margins, verrucous carcinoma should be carefully considered in the differential diagnosis of a warty foot lesion in the setting of the diabetic foot.

\section{INTRODUCTION}

Diabetic foot ulcers are a common complication of chronic uncontrolled diabetes, and the lifetime incidence of foot ulcers is estimated to affect $19 \%$ to $34 \%$ of people with diabetes. ${ }^{1}$ Diabetic foot ulceration is often complicated by other diabetic symptoms, including severe peripheral neuropathy, peripheral arterial disease, and systemic immunosuppression. ${ }^{2}$ Foot ulcers place patients at significant risk of infection, as more than half of ulcers become infected, ${ }^{3}$ potentially leading to sepsis or lower limb amputation in approximately $20 \%$ of moderate or severe diabetic foot infections. ${ }^{1,4,5}$ Therefore, management of chronic diabetic foot ulcers comprises represents a significant area of concern in primary care of diabetic patients.

$A$ rare and often unappreciated sequelae of diabetic foot ulceration is malignant transformation resulting in verrucous carcinoma. Verrucous carcinoma is classically considered a variant of squamous cell carcinoma, which forms painful lesions marked by an exophytic appearance, with deep invasion into local underlying structures. $^{6,7}$ Ackerman first described verrucous carcinoma in the oral cavity, associated with chewing tobacco, ${ }^{7}$ and verrucous carcinoma of the oral cavity has been so closely associated with the use of snuff and chewing tobacco that is has been 
called the "snuff dipper's cancer". 8 However, verrucous carcinoma has been reported to arise outside of the oral cavity in the larynx, the genitalia, and the foot. ${ }^{9}$ The association between verrucous carcinoma of the foot and diabetes is less well known.

Here we have conducted a systematic review of literature describing verrucous carcinoma developing secondary to a diabetic foot ulcer. This is an important item on differential diagnosis of dermatologic deformity secondary to diabetic foot ulceration, particularly as the warty appearance of these carcinomas may mimic more common foot pathology. Verrucous carcinoma, when diagnosed early, is treatable, but any delay in treatment may increase the degree of local invasion, and it therefore should not be overlooked as a diagnosis. This article represents the most comprehensive review to date of published cases describing verrucous carcinoma arising secondary to diabetic foot ulcers, and provides important insights into the presentation and management of this rare complication of diabetes.

\section{METHODS}

We retrieved all articles containing the search term "verrucous carcinoma" and "diabetic foot ulcer" in the abstract or title that had been published in PubMed (www.pubmed.com) before September 2020. Until that time, there had been no systematic reviews or meta-analyses analyzed following PRISMA guidelines. ${ }^{10}$ Sixteen publications were analyzed in more detail, of which six met the requirements to be included in our review. The selection was made by two authors ( $\mathrm{KN}$ and $\mathrm{AO}$ ). There were no discrepancies in the lists of articles selected by the two authors. The requirement for inclusion in our report were that the patient data had been documented in a case-related manner and the patient diagnosed with verrucous carcinoma secondary to diabetic foot lesion. One case of carcinoma cuniculatum ${ }^{11}$ and one case of Ackerman carcinoma ${ }^{12}$ were included in our analysis, as these are classified as alternate names for verrucous carcinoma. ${ }^{6}$ One case report $^{13}$ included two separate cases of verrucous carcinoma secondary to diabetic ulcer in the same patient, for a total of seven such cases across six case reports. Finally, we did not include articles that described patients with different disorders such as verrucous skin lesions, verrucous hyperplasia, etc. that were not verrucous carcinoma. Data collected included gender, age at the time of diagnosis, comorbidities, lesion location and size, lesion duration prior to verrucous carcinoma diagnosis, histological and gross pathological features, treatment approach, and recurrence status. A quantitative meta-analysis of outcomes to treatment was not possible based on the limited number of total reported cases in the literature and variations in longitudinal follow-up.

\section{RESULTS}

\section{Diabetes History}

Patients included both men ${ }^{11,14,15,16}$ and women, ${ }^{12,13}$ with ages ranging from 44 to 72 years old (Table 1). Across the six reported cases, all patients had a past history of diabetic foot ulcers followed by histopathological confirmed diagnosis of verrucous carcinoma arising in the region of the ulcer. Only two of six studies reported $\mathrm{HbA1c}$ as an objective metric of diabetes control (Case $1 \mathrm{HbA} 1 \mathrm{c}=5.9 \% 12$, Case 3 $\mathrm{HbA1c}=7.7 \% 14)$. Cases did not uniformly describe the severity of diabetes, though 5/6 cases specify that the patient's diabetes was poorly controlled with several diabetic 
Table 1. Summary of Patient Characteristics.

\begin{tabular}{|c|c|c|c|c|c|c|}
\hline & Demographics & Diabetes History & $\begin{array}{l}\text { Lesion } \\
\text { location }\end{array}$ & $\begin{array}{l}\text { Lesion } \\
\text { duration }\end{array}$ & $\begin{array}{l}\text { Treatment } \\
\text { Approach }\end{array}$ & Recurrence \\
\hline $\begin{array}{l}\text { Case 1: } \\
\text { Dörr et al. }\end{array}$ & 72 y/o female & $\begin{array}{l}\text { peripheral artery } \\
\text { disease, neuropathy, } \\
\text { stage G3bA2 } \\
\text { nephropathy, previous } \\
\text { partial amputations and } \\
\text { revascularizations of the } \\
\text { foot }\end{array}$ & $\begin{array}{l}\text { R Medial } \\
\text { foot }\end{array}$ & 8 years & $\begin{array}{l}\text {-Primary tumor } \\
\text { excision } \\
\text {-Second resection } \\
\text { with tumor free } \\
\text { margins } \\
\text {-Split-skin graft } \\
\text { and negative } \\
\text { pressure wound } \\
\text { therapy }\end{array}$ & $\begin{array}{l}\text { No long-term } \\
\text { follow-up }\end{array}$ \\
\hline \multirow[t]{2}{*}{$\begin{array}{l}\text { Case 2: } \\
\text { Di Palma } \\
\text { et al. }\end{array}$} & $44 \mathrm{y} / \mathrm{o}$ female & $\begin{array}{l}\text { uncontrolled type } 2 \\
\text { diabetes with severe } \\
\text { peripheral neuropathy in } \\
\text { both feet }\end{array}$ & $\begin{array}{l}\text { R Plantar } \\
1^{\text {st }} \text { MTP }\end{array}$ & $\sim 1$ year & $\begin{array}{l}\text {-Primary wide } \\
\text { excision } \\
\text {-Secondary Mohs } \\
\text { resection }\end{array}$ & $\begin{array}{l}\text { Recurrence at } \\
14 \text { months, } \\
\text { no longer- } \\
\text { term follow-up }\end{array}$ \\
\hline & & & $\begin{array}{l}\text { L Plantar } \\
5^{\text {th }} \text { MTP }\end{array}$ & $\begin{array}{l}\sim 5 \\
\text { months }\end{array}$ & -Mohs resection & $\begin{array}{l}\text { No long-term } \\
\text { follow-up }\end{array}$ \\
\hline $\begin{array}{l}\text { Case 3: } \\
\text { Priesand } \\
\text { et al. }\end{array}$ & $62 \mathrm{y} / \mathrm{o}$ male & $\begin{array}{l}\text { type } 1 \text { diabetes, } \\
\text { neuropathy with renal } \\
\text { insufficiency, } \\
\text { hypertension, } \\
\text { hyperlipidemia, diabetic } \\
\text { retinopathy, multiple } \\
\text { digital amputations }\end{array}$ & $\begin{array}{l}\text { L Plantar } \\
1^{\text {st }} \text { MTP }\end{array}$ & 1 month & $\begin{array}{l}\text {-Wide excision } \\
\text { with tumor-free } \\
\text { margins } \\
\text {-Partial first ray } \\
\text { and hallux } \\
\text { amputation }\end{array}$ & $\begin{array}{l}\text { No long-term } \\
\text { follow-up }\end{array}$ \\
\hline $\begin{array}{l}\text { Case 4: } \\
\text { Nakamura } \\
\text { et al. }\end{array}$ & $66 \mathrm{y} / \mathrm{o}$ male & $\begin{array}{l}\text { insulin-dependent } \\
\text { diabetes, neuropathy }\end{array}$ & $\mathrm{R}$ sole & 6 years & $\begin{array}{l}\text {-Excision with } 1 \\
\mathrm{~cm} \text { margin }\end{array}$ & $\begin{array}{l}\text { No } \\
\text { recurrence at } \\
12 \text { months }\end{array}$ \\
\hline $\begin{array}{l}\text { Case 5: } \\
\text { Penera et } \\
\text { al. }\end{array}$ & $44 \mathrm{y} / \mathrm{o}$ male & $\begin{array}{l}\text { uncontrolled type } 2 \\
\text { diabetes }\end{array}$ & $\begin{array}{l}\text { R Dorsal } \\
1^{\text {st }} \text { MTP }\end{array}$ & 1 year & $\begin{array}{l}\text {-Wide excision } \\
\text {-Full thickness skin } \\
\text { graft }\end{array}$ & $\begin{array}{l}\text { No } \\
\text { recurrence at } \\
12 \text { months }\end{array}$ \\
\hline $\begin{array}{l}\text { Case 6: } \\
\text { Lozzi et } \\
\text { al. }\end{array}$ & $72 \mathrm{y} / \mathrm{o}$ male & $\begin{array}{l}\text { 15-year history of } \\
\text { diabetes mellitus }\end{array}$ & $\mathrm{R}$ sole & 6 years & -Tumor Excision & $\begin{array}{l}\text { No } \\
\text { recurrence at } \\
36 \text { months }\end{array}$ \\
\hline
\end{tabular}

complications including: diabetic neuropathy $(n=4)$, kidney manifestations $(n=2)$, and previous partial amputations $(n=2)$. Table 1 lists the complications detailed in each case. No patients were described as having a history of cutaneous malignant tumors or other predisposing risk factors, with the exception of Case 1 who admitted to smoking, nor were they described as taking any immunosuppressive medications (i.e. steroids, chemotherapy, etc).

\section{Presentation and Timeline}

Carcinomatous lesions arose from foot ulcers ranging in size from 1 to $7 \mathrm{~cm}$ in width, all occurring in the forefoot. Patient ulcers had a peripheral hyperkeratotic border with subsequent wart or cauliflower-like transformation. Malodorous secretions were described in several cases, ${ }^{12,13,16}$ although one case specifically noted a lack of malodor or drainage. ${ }^{14}$ Verrucous carcinoma was diagnosed over a very short or long period following initial ulcer development, presenting in a range from 1 month $^{14}$ to 8 years. ${ }^{12}$ Only a single patient ${ }^{13}$ reported pain in the lesion, with the rest reporting painless presentation throughout the disease course, a finding which may be explained by concurrent peripheral neuropathy. Case 3 
illustrates that it is possible for verrucous carcinoma to develop even after a previously active ulcer is considered healed and closed, as carcinomatous transformation in this patient was noted at the 1 month follow up appointment post wound closure. ${ }^{14}$ Presentation was primarily unilateral, with the exception of a single patient who developed carcinomatous transformation in an ulcer of the left foot after previous transformation and treatment of a verrucous carcinoma arising from an ulcer of the right foot. ${ }^{13}$

\section{Diagnosis and Treatment}

Verrucous carcinoma significantly overlaps in presentation with common foot dermatopathology, and was misdiagnosed as a straightforward diabetic foot ulcer (Cases 1, 2, 3, 5), verrucous skin lesions on the feet in the setting of diabetic neuropathy (Case 4), and plantar wart (Case 6). However, wound debridement and cryotherapy were ineffective in treatment of verrucous carcinoma. Lesions were diagnosed following biopsy, and definitive surgical treatment included excision of the lesion with tumor-free margins, curative in five of the six clinical cases, with varying length of follow-up. However, Case 2 experienced recurrence of the lesion 14 months after primary excision, and thus a Mohs surgery was performed on the recurrent lesion and as primary treatment for the subsequent verrucous carcinoma observed on the contralateral foot in that patient.

\section{DISCUSSION}

This article presents a comprehensive review of the literature to date describing malignant transformation of diabetic foot ulcers into verrucous carcinoma, and provides important insights into the presentation and treatment of this rare diabetic complication. To date, descriptions of verrucous carcinoma in the literature have been sparse and potentially misleading in the context of diabetes, describing a classic clinical presentation of painful ulcers most often localized in the throat. $6,7,8$ Cases of chronic diabetic foot ulcers resulting in verrucous carcinoma of the foot are comparatively under-appreciated. Further study of this transformation is needed to determine molecular drivers and predictors of cancer development among patients, and we have collected here the clinical information on these cases available to date. Critically, we find that among 6 described cases of diabetic foot ulcer resulting in verrucous carcinoma, only a single patient reported pain in the area of the lesion. Therefore, concurrent diabetic neuropathy effectively disguises the typical presentation of this carcinoma. Instead, reported cases describe warty or cauliflower like lesions arising over months to years following development of diabetic foot ulcers with no associated pain. This presentation mimics a range of more common dermatological diagnoses including plantar warts. However, it is unresponsive to the first-line treatments for these more benign diagnoses including cryotherapy and wound debridement.

Clinically, patients presenting with warty lesions in the setting of chronic diabetic foot ulcers and refractory to repeated first-line plantar wart treatment should be promptly biopsied for pathological assessment of verrucous carcinoma as a "do-not-miss" diagnosis. Reports suggest effectiveness of surgical intervention in such cases, with 5 out of 6 patients cured by total excision of the lesion with tumor-free margins. A single patient required Mohs surgery for curative treatment, which was subsequently applied in the first line on a recurrent tumor in the contralateral foot, but the relative rarity of 
this presentation is difficult to assess from the extent of current literature.

Increased awareness of verrucous carcinoma as a consequence of diabetic ulceration will result in larger cohorts of reported patients and their response to varying treatment approaches, enabling more comprehensive assessment of excision vs. Mohs surgery as a first line surgical approach. Most importantly, physicians should strongly consider the possibility of malignant transformation in chronic diabetic foot ulcers as a mimic of more benign foot pathology in any treatment-refractory cases, since surgical therapy appears effective, and early intervention in these cases may greatly reduce the degree of local tissue invasion and subsequent post-surgical morbidity.

\section{Conflict of Interest Disclosures: None}

Funding: None

\section{Corresponding Author:}

Kayla Neville, MS

New York College of Podiatric Medicine

53 E 124th St, New York, NY 10035

Phone: 631-456-9961

Email: kneville2023@nycpm.edu

\section{References:}

1. Armstrong DG, Boulton AJ, Bus SA: Diabetic foot ulcers and their recurrence. New England Journal of Medicine 376: 2367, 2017.

2. Nathan DM: Long-term complications of diabetes. New England Journal of Medicine 328: 1676, 1993.

3. Prompers L, Huijberts M, Apelqvist J, et al.: High prevalence of ischaemia, infection and serious comorbidity in patients with diabetic foot disease in Europe. Baseline results from the Eurodiale study. Diabetologia 50: 18, 2007.

4. Lipsky BA, Berendt AR, Cornia PB, et al.: 2012 Infectious Diseases Society of America clinical practice guideline for the diagnosis and treatment of diabetic foot infections. Clinical infectious diseases 54: e132, 2012.
5. Lavery LA, Armstrong DG, Wunderlich RP, et al.: Diabetic foot syndrome: evaluating the prevalence and incidence of foot pathology in Mexican Americans and non-Hispanic whites from a diabetes disease management cohort. Diabetes care 26: 1435, 2003.

6. Devaney KO, Ferlito A, Rinaldo A, et al.: Verrucous carcinoma (carcinoma cuniculatum) of the head and neck: what do we know now that we did not know a decade ago?. European Archives of Oto-Rhino-Laryngology 268: 477, 2011.

7. Ackerman LV: Verrucous carcinoma of the oral cavity. Surgery 23: 670, 1948.

8. Santoro A, Pannone G, Contaldo M, et al.: A troubling diagnosis of verrucous squamous cell carcinoma ("the bad kind" of keratosis) and the need of clinical and pathological correlations: a review of the literature with a case report. Journal of skin cancer 2011: 370605, 2011.

9. Kraus FT, Perez-Mesa C: Verrucous carcinoma. Clinical and pathologic study of 105 cases involving oral cavity, larynx and genitalia. Cancer 19: 26, 1966.

10. Moher D, Liberati A, Tetzlaff J: Preferred reporting items for systematic reviews and metaanalyses: the PRISMA statement. PLoS med 6: e1000097, 2009.

11. Lozzi GP, Peris K: Carcinoma cuniculatum. Cmaj 177: 249, 2007.

12. Dörr S, Lucke-Paulig L, Vollmer C, et al.: Malignant Transformation in Diabetic Foot Ulcers-Case Reports and Review of the Literature. Geriatrics, 4: 62. 2019

13. Di Palma V, Stone JP, Schell A, et al.: Mistaken Diabetic Ulcers: A Case of Bilateral Foot Verrucous Carcinoma. Case reports in dermatological medicine 2018: 4192657, 2018.

14. Priesand SJ, Holmes CM: Malignant Transformation of a Site of Prior Diabetic Foot Ulceration to Verrucous Carcinoma: A Case Report. Wounds: a compendium of clinical research and practice 29: E125, 2017.

15. Nakamura $Y$, Kashiwagi K, Nakamura A, et al.: Verrucous carcinoma of the foot diagnosed using p53 and Ki-67 immunostaining in a patient with diabetic neuropathy. The American Journal of Dermatopathology 37: 257, 2015.

16. Penera KE, Manji KA, Craig AB, et al.: Atypical presentation of verrucous carcinoma: a case study and review of the literature. Foot \& Ankle Specialist 6: 318, 2013. 